Mišela Amanović, mag. oec.

doc. dr. sc. Martina Solenički ${ }^{1}$

\title{
EUROSKEPTICIZAM MLADIH U HRVATSKOJ
}

\author{
Pregledni rad / Review paper \\ UDK/UDC: 327.39-053.6(497.5) \\ DOI: $10.51650 /$ ezrvs.15.3-4.7 \\ Primljeno / Received: 20/11/2021 \\ Prihvaćeno / Accepted: 5/12/2021
}

Financijska kriza iz 2009. godine koja je rezultirala ekonomskom divergencijom zemalja članica europodručja potaknula je rast euroskepticizma diljem Europske unije. S očekivanim ulaskom Hrvatske u europodručje ponovno se aktualiziralo pitanje troškova i koristi europskih integracija. Glavni cilj rada je istražiti euroskepticizam mladih u Hrvatskoj. Istraživanje je provedeno na uzorku od 405 mladih. Analiza je provedena korištenjem logističke regresije. Zavisna varijabla u modelu je binomna varijabla koja opisuje odgovor ispitanika na pitanje podržavaju li ili ne euro kao službenu valutu u Hrvatskoj. Rezultati istraživanja ukazuju na to da su značajne odrednice euroskepticizma mladih isključivi nacionalni identitet i ekonomska očekivanja. S jedne strane, ulazak Hrvatske u europodručje dijelom je u suprotnosti s osjećajem privrženosti vlastitoj državi u kontekstu isključivog nacionalnog identiteta. Drugim riječima, mladi koji ne smatraju europski identitet dijelom vlastitog identiteta priklonit će se euroskepticizmu. Druga značajna odrednica euroskepticizma mladih su ekonomska očekivanja, odnosno njihova procjena prednosti i nedostataka pridruživanja europodručju. Drugim riječima, mladi formiraju mišljenje o euru na individualnim i društvenim ekonomskim troškovima eura kao službene valute, pa će oni koji očekuju više štete nego koristi, biti skloniji euroskepticizmu. Rezultati istraživanja doprinose boljem razumijevanju odrednica euroskepticizma mladih u Hrvatskoj te mogu biti poticaj da se dodatno otvori medijski i društveni prostor za artikulaciju argumenata o koristima, ali i troškovima budućeg članstva Hrvatske u Ekonomskoj i monetarnoj uniji.

Ključne riječi: Ekonomska i monetarna unija, zajednička valuta, euroskepticizam, mladi, Republika Hrvatska.

\section{Uvod}

Nakon početnog razdoblja stabilnosti i optimizma unutar Ekonomske i monetarne unije (EMU), ideja europskih integracija stavljena je pod upitnik prelijevanjem financijske krize iz SAD-a na europodručje 2009. godine. Kriza je iznjedrila na površinu strukturne razlike između država članica, ukazala na slabosti institucionalnog okvira funkcioniranja europske EMU i

${ }^{1}$ Ekonomski fakultet Sveučilišta u Zagrebu; e-mail: mnakic4@net.efzg.hr 
dovela u pitanje opstanak zajedničke valute. Navedeno je dovelo do porasta euroskepticizma u različitim oblicima i različitog intenziteta diljem Europske unije.

U srpnju 2019. godine hrvatska vlada je uputila zemljama članicama europodručja pismo namjere o ulasku u Europski tečajni mehanizam II (ERM II) što je korak koji prethodi uvođenju eura kao službene valute u Hrvatskoj. Godinu dana kasnije, u srpnju 2020. godine, Hrvatska je i službeno ušla u ERM Il u kojem treba biti najmanje dvije godine kako bi mogla uvesti euro. Navedeno je otvorilo nekoliko važnih pitanja u javnosti: žuri li se s uvođenjem eura, kad je idealan trenutak za pristupanje europodručju, hoće li Hrvatska osjetiti više koristi ili troškova od zajedničke valute i sl. U kontekstu navedenog, provedeno je i nekoliko istraživanja javnog mijenja o zajedničkoj valuti među cijelom populacijom. Ovim istraživanjem daje se doprinos ovaj raspravi kroz ispitivanje možda i najosjetljivije društvene skupine - mladih.

Glavni cilj rada je istražiti euroskepticizam mladih u Hrvatskoj. Fokus ovog istraživanja jest na društvenoj skupini koju čine mladi u dobi od 18 do 29 godina. Ova ciljna skupina odabrana je jer mladi igraju važnu ulogu u razvoju društva, skloni su kritiziranju postojećih društvenih okolnosti, otvoreni su za promjene i pokretači su istih te su jedan od najvažnijih elemenata socijalnog kapitala svakog društva. Stoga je i velik broj politika Europske unije usmjeren na postizanje većeg stupnja uključenosti mladih i poboljšanje njihovog položaja u društvu. Dodatno, ispitivanje je provedeno među studentima Ekonomskog fakulteta Sveučilišta u Zagrebu jer se pretpostavlja da su studenti ekonomije dovoljno upoznati s troškovima i koristima uvođenja zajedničke valute te stoga mogu argumentirano kreirati stavove.

Rad je strukturiran na sljedeći način. Nakon uvoda, u drugom dijelu rada analizirani su različiti aspekti euroskepticizma te je dan pregled dosadašnjih istraživanja stajališta o uvođenju eura u Hrvatskoj. U trećem dijelu rada dan je opis podataka i prikazana je metodologija istraživanja. Rezultati istraživanja prikazani su i analizirani u četvrtom dijelu rada. U zaključku rada istaknute su ključne spoznaje do kojih se došlo istraživanjem, ograničenja istraživanja i preporuke za buduća istraživanja.

\section{Euroskepticizam u teoriji i u Hrvatskoj}

Euroskepticizam je složena višedimenzionalna pojava koju je nemoguće jednoznačno definirati i do koje dolazi iz različitih razloga. Prema Kordić (2011.) euroskepticizam podrazumijeva određeni stupanj otpora prema europskom integracijskom procesu, a koji se kreće od djelomičnog neprihvaćanja usmjerenoga prema pojedinim dijelovima tog procesa pa sve do njegovog potpunog odbijanja.

Važno je napomenuti da euroskepticizam ne znači nužno isključivo protivljenje europskim integracijama, već može podrazumijevati i podršku istima, ali uz kritičko preispitivanje određenih politika ili pak smjera u kojemu idu europske integracije.

Euroskepticizam se najčešće dijeli na tvrdi i meki euroskepticizam. Tvrdi euroskepticizam u teorijskom smislu podrazumijeva potpuno odbacivanje cjelokupnog projekta europske političke i ekonomske integracije i protivljenje ulasku ili ostanku zemlje u EU. Meki euroskepticizam podrazumijeva kontingentno ili uvjetno protivljenje europskom integracijskom procesu te se može podijeliti na 'politički' euroskepticizam (protivljenje postojećim politikama ili proširenjima nadležnosti EU) i euroskepticizam 'nacionalnih interesa' (obrana nacionalnih 
interesa u okviru EU). Obje vrste mekog euroskepticizma su uvjetne jer ne impliciraju načelno protivljenje europskim integracijama, već protivljenje i kritiziranje određenih politika i smjerova integracije. U slučaju određenih promjena, meki euroskeptici bi podržali pa čak i poticali daljnje europsko integriranje. (Taggart, Szczerbiak, 2001.)

Kopecky i Mudde (2002.) razlikuju euroskepticizam s obzirom na opće stajalište prema europskim integracijama (eurofili i eurofobi) te konkretno prema EU (EU-optimisti i EU-pesimisti). Eurofili predstavljaju one koji vjeruju u ključne ideje europske integracije, dok ih eurofobi ne podržavaju. EU-optimisti su zadovoljni okvirom funkcioniranja EU i vjeruju u smjer u kojem se EU razvija, iako mogu izražavati i kritičke stavove prema pojedinim politikama, a EU-pesimisti ne prihvaćaju sadašnji oblik EU ili su zabrinuti zbog smjera njenog razvoja jer primjerice smatraju da značajno odstupa od njihove interpretacije ideja europske integracije. Kombinacijom različitih stajališta prema europskim integracijama s jedne strane i EU $s$ druge strane, moguće je razlikovati euroentuzijaste (kombinirana stajališta eurofila i EU-optimista), euroskeptike (kombinirana stajališta eurofila i EU-pesimista), europragmatike (kombinirana stajališta eurofoba i EU-optimista) i europrotivnike (kombinirana stajališta eurofoba i EU-pesimista).

Kaniok (2009.) razlikuje europejiste kao pobornike nadnacionalne ideje europske integracije, eurogovernmentaliste koji su rezerviraniji i kritičniji prema postojećem modelu integracije i euroskeptike koji se protive europskim integracijama. Flood i Usherwood (2005.) primjenjuju postupnu klasifikaciju u rasponu od bezuvjetne potpore daljnjoj europskoj integraciji do načelnog protivljenja integraciji i članstvu te razlikuju: maksimaliste, reformiste i gradualiste koje ne smatraju euroskepticima te minimaliste, revizioniste i rejektioniste koji predstavljaju nijanse između tvrdog i mekog euroskepticizma.

Euroskepticizam u Hrvatskoj bio je aktualan i u razdoblju donošenja odluke o pristupanju EU kao što je aktualan i danas u vidu propitkivanja ekonomskih i ostalih politika EU, a posebice u kontekstu pristupanja Hrvatske europodručju.

Euroskepticizam u Hrvatskoj sličan je ostalim europskim euroskepticizmima, ali ima i svoje specifičnosti koje su vezane za prošlost i suvremeni hrvatski politički identitet. (Jović, 2012.) Referendum o ulasku Hrvatske u EU pokazao je da je većina građana euroravnodušna, tj. kod većine građana izostaje čvrsti stav ili bilo kakva emotivna povezanost prema EU, njenim institucijama i politikama. Navedeno rezultira pasivnošću koja se izražava neizlaskom na izbore, nesudjelovanjem u raspravama i/ili procesu odlučivanja kada je riječ o EU. (Jović, 2012.)

Milardović (2012.) razlikuje pet oblika euroskepticizma koji su rezultat društvenih rasprava u Hrvatskoj: pragmatični ili utilitarni, socijalni, situacionistički, politički i kulturni. Pragmatični/utilitarni oblik rezultat je analize ekonomskih koristi i troškova sudjelovanja Hrvatske u europskim integracijama. Socijalni oblik euroskepticizma usredotočen je na kvalitetu života i socijalnu sigurnost. Situacionistički oblik euroskepticizma javlja se kao reakcija na unutarnje i vanjske događaje povezane s EU. Politički oblik fokusira se na različita pitanja glede suvereniteta, demokracije i EU kao moguće federacije ili superdržave. Kulturni oblik euroskepticizma rezultat je rasprava o očuvanju kulture i identiteta u europskom okruženju. Nadalje, Milardović (2012.) razlikuje dvije vrste euroskepticizma - elitistički koji se odnosi na stavove političke elite i popularni koji se odnosi na stavove šire javnosti. 
U ovom radu naglasak je na popularnom, tj. shvaćanju europskih integracija od strane građana. U pokušajima znanstvenog objašnjenja odnosa građana prema uključivanju u procese europskih integracija, prema Lamza Posavec i sur. (2006.), prevladavaju dva temeljna pristupa analizi. Prvi pristup se zasniva na klasičnoj teoriji racionalnog izbora, odnosno procjeni gospodarskih i ostalih društvenih troškova i koristi koje proizlaze iz integracije. Što su procijenjene koristi veće u odnosu na troškove, to je snažnija podrška procesima integracije i obrnuto. Drugi pristup, tzv. sociopsihološki, sklonost europskim integracijama dovodi u vezu s nacionalnim identitetom odnosno sa stupnjem identifikacije građana s vlastitom državom i nacijom. Što je taj osjećaj intenzivniji, građani su manje otvoreni prema integracijskim procesima jer uključivanje, neovisno o koristima koje im donosi, doživljavaju kao određeni gubitak nacionalnoga identiteta.

U Hrvatskoj je provedeno nekoliko istraživanja stajališta građana o uvođenju eura. Posljednje istraživanje, provedeno u veljači 2021. godine, pokazalo je da se udio građana koji podržavaju uvođenje eura povećao u odnosu na prethodnu anketu s $41 \%$ na $45 \%$. Uvođenju eura izričito se protivi 19\% (u odnosu na $18 \%$ u prethodnoj anketi) građana, dok je njih 26\% uvjetno za. Što se tiče osoba od 18 do 30 godina (mladi), $38 \%$ ih je za uvođenje eura, $21 \%$ protiv, a $32 \%$ uvjetno za. (HNB, 2021.)

Istraživanje euroskepticizma na primjeru studentske populacije u Hrvatskoj proveli su Kersan-Škabić i Tomić (2009.). Rezultati istraživanja ukazuju da su korijeni euroskepticizma studentske populacije u ekonomskim troškovima ulaska Hrvatske u EU. Kao razlog euroskepticizma, uz gubitak suvereniteta, ističu se strah od siromaštva, iskorištavanje nacionalnih resursa i emigracija. S druge strane, kao pozitivne aspekte članstva u EU ističu bolje mogućnosti zapošljavanja, viši životni standard i učinkovitiju pravnu državu.

\section{Opis podataka i metodologije istraživanja}

Istraživanje euroskepticizma u Hrvatskoj provedeno je među mladima koji su definirani kao društvena grupa u dobi od 18 do 29 godina. Istraživanje je provedeno u rujnu 2020. godine na uzorku od 405 studenata Ekonomskog fakulteta u Zagrebu. Za potrebe istraživanja pripremljen je anketni upitnik u aplikaciji Google Forms. Ispitivanje je bilo u potpunosti anonimno i dobrovoljno, a ispitanicima je na početku upitnika objašnjena svrha istraživanja. Anketni upitnik sastojao se od pitanja zatvorenog tipa s opcijom jednog odgovora i pitanja s ponuđenim odgovorima intenziteta. Na ovaj način dobiveni su kvantitativni podaci za daljnju statističku obradu.

Socio-demografska struktura ispitanika prikazana je u Tablici 1. U uzorku je sudjelovalo $33,6 \%$ ispitanika muškog spola te $66,4 \%$ ispitanika ženskog spola. Najviše ispitanika pripada dobnoj skupini od 22-25 godina (51,8 \% ukupnog broja ispitanika), stanuje na području Grada Zagreba (52,3 \%) te radi preko student servisa, sezonski ili honorarno (46,7 \%). 
Tablica 1. Socio-demografska struktura ispitanika $(\mathrm{N}=405)$

\begin{tabular}{|l|l|c|c|}
\hline \multicolumn{2}{|l|}{} & Broj & Udio \\
\hline \multirow{3}{*}{ Ukupno } & muški & 405 & $100,0 \%$ \\
\hline \multirow{4}{*}{ dob } & ženski & 136 & $33,6 \%$ \\
\hline \multirow{5}{*}{ regija } & $18-21$ & 269 & $66,4 \%$ \\
\cline { 2 - 4 } & $22-25$ & 83 & $20,5 \%$ \\
\cline { 2 - 4 } & $26-29$ & 210 & $51,8 \%$ \\
\hline \multirow{4}{*}{ zaposlenje } & Grad Zagreb & 112 & $27,7 \%$ \\
\cline { 2 - 4 } & Sjeverna Hrvatska & 212 & $52,3 \%$ \\
\cline { 2 - 4 } & Slavonija & 35 & $8,6 \%$ \\
\cline { 2 - 4 } & Banovina, Kordun, Lika & 40 & $9,9 \%$ \\
\cline { 2 - 4 } & Istra, Primorje, Gorski Kotar & 45 & $1,8 \%$ \\
\cline { 2 - 4 } & Dalmacija & 66 & $11,1 \%$ \\
\hline & ugovor o radu & 92 & $16,3 \%$ \\
\cline { 2 - 4 } & student servis i ostalo & 189 & $22,7 \%$ \\
\cline { 2 - 4 } & nezaposlen/a & 124 & $36,7 \%$ \\
\hline
\end{tabular}

Izvor: izrada autorica

Prikupljeni podaci analizirani su korištenjem modela logističke regresije. Zavisna varijabla u modelu je binarna varijabla euroskepticizam koja poprima vrijednost 0 ukoliko ispitanici podržavaju euro kao službenu valutu u Hrvatskoj, a 1 ukoliko ga ne podržavaju. Model binomne logističke regresije koristi se za procjenu vjerojatnosti realizacije jedne od kategorija binomne zavisne varijable na temelju vrijednosti jedne ili više nezavisnih varijabli. (IBM, 2021.) Kao nezavisne varijable izabrane su varijable koje opisuju dva ključna aspekta euroskepticizma - ekonomski te aspekt nacionalnog identiteta za koje se u dosadašnjim istraživanjima pokazalo da su najviše povezani s euroskepticizmom.

Prva nezavisna varijabla nazvana je ekonomska očekivanja, a opisuje stajalište ispitanika o tome hoće li uvođenje eura kao službene valute u Hrvatskoj donijeti više štete ili koristi. Ako je javnost svjesna ekonomskih posljedica (pozitivnih i negativnih) zajedničke valute, pretpostavka je da će stajalište o uvođenju eura temeljiti na analizi troškova i koristi zajedničke valute. Drugim riječima, ako ispitanici očekuju da će imati više štete nego koristi od uvođenja eura, tj. ako imaju negativna ekonomska očekivanja, vjerojatnije je da će se prikloniti euroskepticizmu, tj. da neće podržavati euro kao službenu valutu u Hrvatskoj. Naravno, vrijedi i obrnuto. Definicija varijable proizlazi iz pitanja "Prema Vašem mišljenju, donosi li euro kao službena valuta u Hrvatskoj više koristi ili više štete?" pri čemu su bili mogući odgovori od ' 1 ' (Puno više štete nego koristi) do '5' (Puno više koristi nego štete).

Mnoga istraživanja euroskepticizma ističu nacionalni identitet kao ključno obrazloženje euroskepticizma. S obzirom da se nacionalna valuta smatra jednim od najvažnijih simbola suvereniteta i nacionalnog identiteta, pretpostavlja se da će mladi koji ne smatraju europski identitet dijelom vlastitog identiteta odnosno oni koji ga poimaju isključivo, biti više skeptični prema zajedničkoj valuti od onih koji vlastiti nacionalni identitet poimaju uključivo. Nezavisna varijabla isključivi nacionalni identitet definirana je temeljem postavljanog pitanja 
"Smatrate li europski identitet dijelom vlastitog identiteta?" kao binomna varijabla pri čemu 0 predstavlja odgovor 'da', a 1 'ne'. Opis i mjerenje varijabli prikazano je u tablici 2.

Tablica 2. Operacionalizacija ulaznih varijabli modela

\begin{tabular}{|c|c|c|c|}
\hline Varijabla & Formulacija pitanja & Odgovori i opis kodiranja & $\%$ \\
\hline \multicolumn{4}{|l|}{ Zavisna varijabla } \\
\hline \multirow{2}{*}{ euroskepticizam } & \multirow{2}{*}{$\begin{array}{l}\text { Podržavate li euro } \\
\text { kao službenu valutu } \\
\text { u Hrvatskoj? }\end{array}$} & $0-d a$ & $39,8 \%$ \\
\hline & & $1-$ ne & $60,2 \%$ \\
\hline \multicolumn{4}{|c|}{ Nezavisne varijable } \\
\hline \multirow{5}{*}{$\begin{array}{l}\text { ekonomska } \\
\text { očekivanja }\end{array}$} & \multirow{5}{*}{$\begin{array}{l}\text { Prema Vašem } \\
\text { mišljenju, donosi li } \\
\text { euro kao službena } \\
\text { valuta u Hrvatskoj više } \\
\text { koristi ili više štete? }\end{array}$} & 1 - Puno više štete nego koristi & $25,7 \%$ \\
\hline & & 2 - Nešto više štete nego koristi & $18,0 \%$ \\
\hline & & 3 - Podjednako koristi i štete & $24,9 \%$ \\
\hline & & 4 - Nešto više koristi nego štete & $20,7 \%$ \\
\hline & & 5 - Puno više koristi nego štete & $10,6 \%$ \\
\hline \multirow{2}{*}{$\begin{array}{l}\text { isključivi } \\
\text { nacionalni } \\
\text { identitet }\end{array}$} & \multirow{2}{*}{$\begin{array}{l}\text { Smatrate li europski } \\
\text { identitet dijelom } \\
\text { vlastitog identiteta? }\end{array}$} & $0-d a$ & $69,1 \%$ \\
\hline & & $1-$ ne & $30,9 \%$ \\
\hline
\end{tabular}

Izvor: izrada autorica

Logistička regresijska procedura provedena je uz pomoć SPSS softvera. Analiza varijabli socio-demografskih obilježja ispitanika provedena je na temelju testa uz signifikantnost od $5 \%$, pri čemu se jedino varijabla spol pokazala statistički značajnom pa je uključena u model. S obzirom na to, jedino je varijabla spol uključena kao kontrolna varijabla u model, a ostale varijable socio-demografskih obilježja su izostavljene iz daljnje analize.

\section{Prikaz i analiza rezultata empirijskog istraživanja}

Rezultati provedenog istraživanja pokazuju da većina ispitanika $(60,2 \%)$ ne podržava uvođenje eura kao službene valute u Hrvatskoj. Navedeno je u skladu s posljednjim istraživanjem javnog mijenja gdje je $38 \%$ mladih bilo za uvođenje eura (HNB, 2021.). Više je ispitanika $(43,7 \%)$ koji smatraju da će uvođenje eura donijeti više štete nego koristi u odnosu na ispitanike koji smatraju da će donijeti više koristi nego štete (31,3\%). Ovi rezultati se donekle razlikuju u odnosu na posljednje istraživanje javnog mijenja (HNB, 2021.) gdje je $35 \%$ ispitanika u dobnoj skupini od 18 do 30 godina istaknulo negativne učinke eura, $21 \%$ pozitivne, a najviše neutralne (43\%). Navedeno ukazuje na bolju informiranost studenata ekonomije o koristima i troškovima zajedničke valute zbog čega je udio neutralnih odgovora u ovom istraživanju manji. U konačnici, većina ispitanika $(69,1 \%)$ smatra europski identitet dijelom vlastitog identiteta. $U$ tablici 3 prikazana je deskriptivna statistika varijabli u modelu.

Prema provedenom Hi-kvadrat testu (tablica 4) vidljivo je kako postoji statistički značajna povezanost između varijabli euroskepticizam i isključivi nacionalni identitet, odnosno može se prihvatiti hipoteza kako postoji statistički značajna razlika u pojavi euroskepticizma u odnosu na isključivi nacionalni identitet. 
Tablica 3. Deskriptivna statistika

\begin{tabular}{|c|c|c|c|c|c|c|c|}
\hline & \multicolumn{2}{|c|}{ euroskepticizam } & \multicolumn{2}{|c|}{$\begin{array}{c}\text { isključivi nacionalni } \\
\text { identitet }\end{array}$} & \multicolumn{2}{|c|}{$\begin{array}{l}\text { ekonomska } \\
\text { očekivanja }\end{array}$} \\
\hline \multirow{6}{*}{ Frequency/Percent } & 0 & 161 & 39,8 & 280 & 69,1 & & \\
\hline & 1 & 244 & 60,2 & 125 & 30,9 & 104 & 25,7 \\
\hline & 2 & & & & & 73 & 18,0 \\
\hline & 3 & & & & & 101 & 24,9 \\
\hline & 4 & & & & & 84 & 20,7 \\
\hline & 5 & & & & & 43 & 10,6 \\
\hline \multicolumn{2}{|l|}{ Mean } & \multicolumn{2}{|c|}{60} & \multicolumn{2}{|c|}{31} & 2,73 & \\
\hline \multicolumn{2}{|l|}{ Std. Error of Mean } & \multicolumn{2}{|c|}{,024 } & \multicolumn{2}{|c|}{, 023} &, 066 & \\
\hline \multicolumn{2}{|l|}{ Std. Deviation } & \multicolumn{2}{|c|}{,490 } & \multicolumn{2}{|c|}{463} & 1,330 & \\
\hline \multicolumn{2}{|l|}{ Variance } & \multicolumn{2}{|c|}{,240 } & \multicolumn{2}{|c|}{,214 } & 1,769 & \\
\hline \multicolumn{2}{|l|}{ Skewness } & \multicolumn{2}{|c|}{,- 420} & \multicolumn{2}{|c|}{832} &, 126 & \\
\hline \multicolumn{2}{|l|}{ Std. Error of Skewness } & \multicolumn{2}{|c|}{, 121} & \multicolumn{2}{|c|}{121} & 121 & \\
\hline \multicolumn{2}{|l|}{ Kurtosis } & \multicolumn{2}{|c|}{$-1,832$} & \multicolumn{2}{|c|}{$-1,315$} & $-1,163$ & \\
\hline \multicolumn{2}{|l|}{ Std. Error of Kurtosis } & \multicolumn{2}{|c|}{,242 } & \multicolumn{2}{|c|}{, 242} & ,242 & \\
\hline \multicolumn{2}{|l|}{ Range } & \multicolumn{2}{|c|}{1} & \multicolumn{2}{|c|}{1} & 4 & \\
\hline \multicolumn{2}{|l|}{ Minimum } & \multicolumn{2}{|c|}{0} & \multicolumn{2}{|c|}{0} & 1 & \\
\hline \multicolumn{2}{|l|}{ Maximum } & \multicolumn{2}{|c|}{1} & & & 5 & \\
\hline
\end{tabular}

Izvor: izrada autorica u statističkom programu SPSS

Sukladno pretpostavci logističke regresije da su odnosi između kontinuiranih prediktora i logita (log odds) linearni, provedena je provjera za varijablu ekonomska očekivanja. BoxTidwellov test korišten je za provjeru pretpostavke testiranjem je li transformacija logita linearna funkcija prediktora (IBM, 2021.). Rezultati pokazuju da termin nije značajan (Sig. = 0,395 $>0,05)$, čime je dokazano da je pretpostavka linearnosti zadovoljena (tablica 5).

Tablica 4. Statistička značajnost varijable isključivi nacionalni identitet

\begin{tabular}{|c|c|c|c|c|c|}
\hline & Value & df & $\begin{array}{c}\text { Asymptotic } \\
\text { Significance } \\
\text { (2-sided) }\end{array}$ & $\begin{array}{l}\text { Exact Sig. } \\
\text { (2-sided) }\end{array}$ & $\begin{array}{l}\text { Exact Sig. } \\
\text { (1-sided) }\end{array}$ \\
\hline Pearson Chi-Square & $51,635^{a}$ & 1 & $<, 001$ & & \\
\hline Continuity Correction $^{b}$ & 50,068 & 1 & $<, 001$ & & \\
\hline Likelihood Ratio & 56,976 & 1 & $<, 001$ & & \\
\hline Fisher's Exact Test & & & & $<, 001$ & $<, 001$ \\
\hline Linear-by-Linear Association & 51,508 & 1 & $<, 001$ & & \\
\hline $\mathrm{N}$ of Valid Cases & 405 & & & & \\
\hline
\end{tabular}

a. 0 cells $(0,0 \%)$ have expected count less than 5 . The minimum expected count is 49,69.

b. Computed only for a $2 \times 2$ table

Izvor: izrada autorica u statističkom programu SPSS 
Tablica 5. Box-Tidwellov test

\begin{tabular}{|c|c|c|c|c|c|c|c|}
\hline \multicolumn{2}{|c|}{} & B & S.E. & Wald & df & Sig. & Exp(B) \\
\hline \multirow{3}{*}{ Step 1 $1^{\text {a }}$} & EC_EXP &,- 599 & 1,821 &, 108 & 1 &, 742 &, 549 \\
\cline { 2 - 8 } & trEC_exp &,- 765 &, 898 &, 725 & 1 &, 395 &, 466 \\
\cline { 2 - 8 } & Constant & 4,782 & 2,462 & 3,773 & 1 &, 052 & 119,386 \\
\hline
\end{tabular}

a.Variable(s) entered on step 1: EC_EXP, trEC_exp.

Izvor: ispis iz statističkog programa SPSS

Za razumijevanje relativnog utjecaja svake od ulaznih nezavisnih varijabli (ekonomska očekivanja i isključivi nacionalni identitet) u stvaranju razlika između dvije moguće kategorije zavisne varijable (euroskepticizam) provedena je logistička regresija. Rezultati logističke regresije dani su u tablici 6 . Uz signifikantnost od $5 \%$, statistički su značajne obje nezavisne varijable u modelu (Sig. = 0,049 i Sig. $<0,001$ ), drugim riječima, promjene u nezavisnim varijablama povezane su s promjenama vjerojatnosti pojave euroskepticizma.

Varijabla ekonomska očekivanja ima negativan predznak (koeficijent -2.076), što ukazuje na negativan odnos između nezavisne varijable i predviđene vjerojatnosti. Drugim riječima, promjena prediktora ekonomska očekivanja u vidu povećanja čini pojavu euroskepticizma manje vjerojatnom. S druge strane, varijabla isključivi nacionalni identitet ima pozitivan predznak (koeficijent 0.773 ), što ukazuje na pozitivan odnos između nezavisne varijable i predviđene vjerojatnosti. Stoga, isključivi nacionalni identitet povećava vjerojatnost da će se osoba prikloniti euroskepticizmu.

Tablica 6. Logistička regresijska procedura modela

\begin{tabular}{|l|l|c|c|c|c|c|c|}
\hline \multicolumn{2}{|c|}{} & B & S.E. & Wald & df & Sig. & Exp(B) \\
\hline \multirow{4}{*}{ Step 1 ${ }^{\text {a }}$} & EX_NAT_ID(1) &, 773 &, 393 & 3,882 & 1 &, 049 & 2,167 \\
\cline { 2 - 8 } & EC_EXP & $-2,076$ &, 221 & 88,155 & 1 & $<, 001$ &, 125 \\
\cline { 2 - 8 } & Constant & 6,469 &, 709 & 83,144 & 1 & $<, 001$ & 644,750 \\
\hline
\end{tabular}

\begin{tabular}{|c|l|c|c|}
\hline \multicolumn{2}{|c|}{} & \multicolumn{2}{|c|}{ 95\% C.I.for EXP(B) } \\
\cline { 3 - 4 } \multicolumn{2}{|c|}{} & Lower & Upper \\
\hline \multirow{3}{*}{ Step 1 $1^{\text {a }}$} & EX_NAT_ID(1) & 1,004 & 4,678 \\
\cline { 2 - 4 } & EC_EXP &, 081 &, 194 \\
\cline { 2 - 4 } & Constant & & \\
\hline
\end{tabular}

a. Variable(s) entered on step 1: EX_NAT_ID, EC_EXP, GENDER.

Protumačenost modelom

\begin{tabular}{|c|c|c|c|}
\hline Step & $\begin{array}{c}\mathbf{- 2} \text { Log } \\
\text { likelihood }\end{array}$ & $\begin{array}{c}\text { Cox \& Snell } \\
\text { R Square }\end{array}$ & $\begin{array}{c}\text { Nagelkerke } \\
\text { R Square }\end{array}$ \\
\hline 1 & $258,486^{a}$ &, 506 &, 685 \\
\hline
\end{tabular}

a. Estimation terminated at iteration number 6 because parameter estimates changed by less than ,001. 


\begin{tabular}{|l|c|c|c|}
\hline \multicolumn{4}{|c|}{ Hosmer-Lemeshow test } \\
\hline Step & Chi-square & df & Sig. \\
\hline 1 & 6,186 & 8 &, 626 \\
\hline
\end{tabular}

Klasifikacijska tablica modela ${ }^{a}$

\begin{tabular}{|l|l|c|c|c|c|}
\hline \multirow{2}{*}{} & \multicolumn{2}{|c|}{ Observed } & \multicolumn{3}{c|}{ Predicted } \\
\cline { 4 - 6 } & \multicolumn{2}{|c|}{} & Euroscepticism & Percentage \\
\cline { 3 - 6 } & & 0 & $\mathbf{1}$ & Correct \\
\hline \multirow{3}{*}{ Step 1} & Euroscepticism & 0 & 115 & 232 & 71,4 \\
\cline { 2 - 6 } & & 1 & 12 & & 95,1 \\
\cline { 2 - 6 } & Overall Percentage & & & 85,7 \\
\hline
\end{tabular}

a. The cut value is , 500

Omnibus test ${ }^{a}$

\begin{tabular}{|l|l|c|c|c|}
\hline \multicolumn{2}{|c|}{} & Chi-square & df & Sig. \\
\hline \multirow{4}{*}{ Step 1} & Step & 285,832 & 3 & 0,000 \\
\cline { 2 - 5 } & Block & 285,832 & 3 & 0,000 \\
\cline { 2 - 5 } & Model & 285,832 & 3 & 0,000 \\
\hline
\end{tabular}

\begin{tabular}{|c|c|c|}
\hline Likelihood Ratio Chi-Square & df & Sig \\
\hline 285,832 & 3 &, 000 \\
\hline
\end{tabular}

Dependent Variable: EUROSCEPTICISM

Model: (Intercept), GENDER, EX_NAT_ID, EC_EXP

a. Compares the fitted model against the intercept-only model.

Izvor: izrada autorica u statističkom programu SPSS

Nezavisne varijable u modelu predviđaju u koju od dvije kategorije binarne zavisne varijable će pojedina osoba pripasti, odnosno hoće li se osoba prikloniti euroskepticizmu ili bi podržala euro kao službenu valutu u Hrvatskoj. Odds ratio $(\operatorname{Exp}(\mathrm{B}))$ za varijablu ekonomska očekivanja iznosi 0.125 , što znači da je manje vjerojatna pojava euroskepticizma ukoliko se prediktor poveća. Omjer koeficijenata pokazuje da za povećanje prediktora za 1 jedinicu, izgledi za euroskepticizam odnosno protivljenje euru su sedam puta manji od izgleda da će osoba podržati euro. Odds ratio (Exp(B)) za varijablu isključivi nacionalni identitet iznosi 2.167 te podrazumijeva da su izgledi za euroskepticizam kod onih koji ne smatraju europski identitet dijelom vlastitog identiteta 2,167 puta veći u odnosu na one koji europski identitet smatraju dijelom vlastitog identiteta.

Protumačenost modelom dana je preko tri mjere: -2 Log likelihood, Cox \& Snell $\mathrm{R}^{2}$ i Nagelkerke $R^{2}$. Vrijednost -2LL $(258,486)$ uspoređuje se $s-2 L L$ za osnovni model pomoću omnibus testa koeficijenata modela kako bi se ustanovilo radi li se o značajnom poboljšanju $(p<0,05)$ u odnosu na osnovni model. Budući da je došlo do značajnog smanjenja -2LL, odnosno da je model s uključenim eksplanatornim varijablama značajno bolje prilagođen od osnovnog modela, model je prihvatljiv na statistički značajnoj razini, $x^{2}(3)=285.83, p<0,00$. Može se 
reći da je skup nezavisnih varijabli u predloženom modelu značajan za poboljšanje procjene modela. Cox \& Snell $R^{2}$ i Nagelkerke $R^{2}$ tvz. pseudo $R^{2}$ mjere odražavaju postotak varijacija $u$ odgovoru koji je objašnjen modelom. Model objašnjava između 50,6\% i 68,5\%, što upućuje na to da su predviđanja prilično pouzdana, ali ukazuje i na mogućnost dodavanja dodatnih prediktora u model. Ocjena prikladnosti modela (engl. goodness of fit) može se iščitati iz Hosmer-Lemeshowova testa koji pokazuje dobru prilagođenost modela podacima (Sig. = 0,626), odnosno da je model dobro kalibriran. Kako bi se procijenilo koliko dobro logistički regresijski model odgovara skupu podataka, promatraju se dva mjerna podatka: osjetljivost i specifičnost. Pouzdanost klasificiranja euroskepticizma je 95,1\% (specifičnost), dok je pouzdanost klasifikacije onih koji bi podržali euro 71,4\% (osjetljivost). Ukupna vjerojatnost postignute ispravne klasifikacije iznosi $85,7 \%$ ili drugim riječima, stopa pogodaka za pojavu euroskepticizma iznosi $85,7 \%$.

Dobiveni rezultati istraživanja ukazuju kako su i ekonomska očekivanja i isključivi nacionalni identitet značajni prediktori euroskepticizma. Kako bi se detaljnije ispitali stavovi mladih, postavljena su im pitanja i o najvažnijim prednostima i nedostacima uvođenja eura u Hrvatskoj. Na grafikonu 1 prikazani su odgovori ispitanika na pitanje što smatraju najvažnijim nedostacima uvođenja eura.

\section{Grafikon 1. Stajališta ispitanika o nedostacima uvođenja eura}

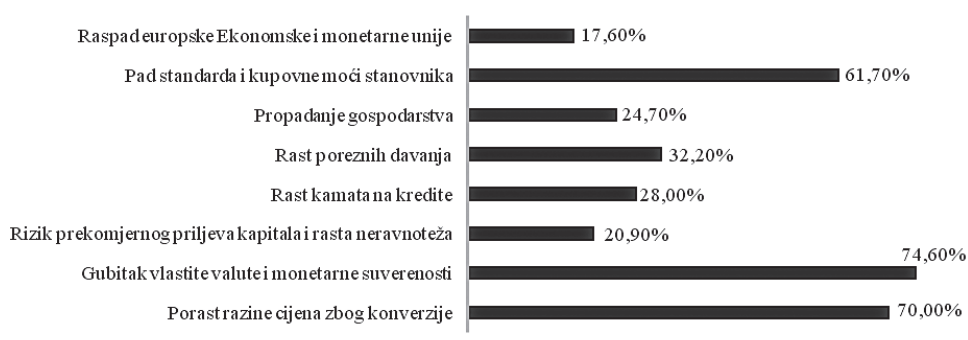

Izvor: izrada autorica

$S$ jedne strane, čini se da zabrinutost zbog rasta cijena nakon uvođenja eura i gubitka kupovne moći umanjuje potporu uvođenju eura. Naime 70 \% ispitanika kao najvažniji nedostatak ističe porast razine cijena zbog konverzije, a 61 \% pad standarda i kupovne moći stanovnika. Porast razine cijena najvažniji je rizik uvođenja zajedničke valute i prema istraživanjima javnog mijenja (HNB, 2021.). Ipak, najveći broj ispitanika $(74,6 \%)$ kao glavni nedostatak navodi gubitak vlastite valute i monetarne suverenosti. S obzirom na to da gotovo $70 \%$ ispitanika europski identitet smatra vlastitim identitetom, gubitak vlastite valute i monetarne suverenosti kao trošak monetarnog integriranja trebalo bi tumačiti u ekonomskom kontekstu prije nego $u$ kontekstu nacionalnog identiteta. Može se zaključiti kako mladi gubitak vođenja autonomne monetarne i tečajne politike percipiraju bitnim za hrvatsko gospodarstvo. 
Grafikon 2. Stajališta ispitanika o prednostima uvođenja eura

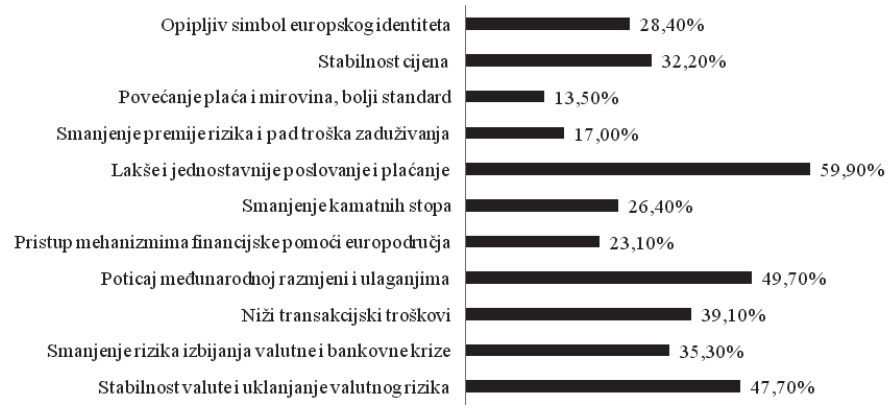

Izvor: izrada autorica

Na grafikonu 2. prikazani su odgovori ispitanika na pitanje što smatraju najvažnijim prednostima uvođenja eura pri čemu je najviše ispitanika kao glavnu prednost istaklo lakše i jednostavnije poslovanje, poticaj međunarodnoj razmjeni te stabilnost valute i uklanjanje valutnog rizika što je u skladu i s dosadašnjim ispitivanjima javnog mijenja u Hrvatskoj.

Konačno, iako ovo istraživanje daje uvid u razinu te odrednice i izvore euroskepticizma mladih u Hrvatskoj, njegove rezultate treba vrednovati i tumačiti ovisno o kontekstu u kojem su podaci prikupljeni. Rezultati provedenog istraživanja ne mogu pružiti zaključke reprezentativne za sve mlade u Hrvatskoj, kao ni za opću populaciju. Proširivanje istraživanja na širi krug ispitanika doprinijelo bi reprezentativnosti rezultata. Konačno, formiranje drukčijeg seta pitanja i uvrštavanje drugih varijabli kao odrednica euroskepticizma (npr. (ne)povjerenje u institucije) potencijalni su smjerovi daljnjeg istraživanja. Neovisno o ovim ograničenjima, rezultati ovog istraživanja mogu biti vrijedan input nositeljima političkih i ekonomskih odluka.

\section{Zaključak}

Euroskepticizam ne treba gledati isključivo kao negativnu pojavu, već ga treba tumačiti kao propitkivanje te vaganje koristi i šteta od ekonomskih i monetarnih integracija, kao i kritiku izostanka konstruktivne rasprave o pozitivnim i negativnim implikacijama članstva u EMU. S obzirom na skoro priključenje Republike Hrvatske europodručju provedeno je istraživanje stajališta mladih o uvođenju eura. Rezultati istraživanja pokazuju da su za predikciju euroskepticizma kod mladih značajne varijable isključivi nacionalni identitet i ekonomska očekivanja. Drugim riječima, onaj dio mladih koji ne smatra europski identitet dijelom vlastitog identiteta, priklonit će se euroskepticizmu. Također, mladi koji smatraju da će uvođenje eura donijeti više troškova nego koristi, bit će skloniji euroskepticizmu.

Rezultate istraživanja treba tumačiti s oprezom s obzirom na strukturu uzorka (studenti ekonomije) i uključene varijable. Proširivanje istraživanja na širi krug ispitanika, formiranje drukčijeg seta pitanja i uvrštavanje drugih varijabli kao odrednica euroskepticizma, preporuke su za buduća istraživanja. Unatoč ograničenjima, istraživanje daje uvid u stajališta mladih o uvođenju eura. 
Rezultati istraživanja pokazuju podijeljenost mladih u podršci uvođenju eura. Navedeno je u skladu s podijeljenošću cijelog društva o ovom pitanju. Činjenica da je podrška uvođenju eura na razini društva manja od $50 \%$, a kod mladih manja i od $40 \%$, ukazuje na to da je potrebno u medijskom i društvenom prostoru poticati argumentirane rasprave o koristima, ali i troškovima uvođenja eura u Hrvatskoj. Kontinuirano preispitivanje implikacija uvođenja zajedničke valute pri tome ne treba gledati isključivo kao negativnu pojavu. Naprotiv, informirana stručna i znanstvena rasprava može u konačnici doprinijeti boljem razumijevanju i većoj podršci europskim integracijama. Pri tome posebnu pozornost treba posvetiti osluškivanju stajališta mladih budući da o njima ovisi budućnost europskih integracijskih procesa.

\section{LITERATURA}

1. Flood, C. i Usherwood, S. (2005.) Positions, Dispositions, Transitions: A model of group alignment on EU integration, 55th annual conference of the Political Studies Association, University of Leeds, str. 1-18

2. HNB (2021.) Istraživanje javnog mnijenja o uvođenju eura. Dostupno na: https://www.hnb. hr/documents/20182/3721069/hn19032021_Istrazivanje_javnog_mnijenja_o_uvodjenju_eura_ozujak_2021.pdf/7162cd76-a346-6698-e04a-60a5eaa240f2?t=1616165838705 (pristup: 01.09.2021.)

3. IBM (2021.) SPSS Statistics: Logistic Regression. IBM, New York City. Dostupno na: https:// www.ibm.com/docs/en/spss-statistics/28.0.0?topic=regression-logistic (pristup: 03.09.2021.)

4. Jović, D. (2012.) Hrvatski referendum o članstvu u Europskoj uniji i njegove posljedice za smanjeni Zapadni Balkan, Anali Hrvatskog politološkog društva, Vol. 9, No. 1, str. 163-182

5. Kaniok, P. (2009.) Europeanists, Eurogovernmentalists, and Eurosceptics: A constructive Critisism of Previous Research, U: Arató, K. i Kaniok, P. (ur.) Euroscepticism and European Integration, Centar za politološka istraživanja, Zagreb, str. 159-179

6. Kersan-Škabić, I., Tomić, D. (2009.) Recognising Euroscepticism in Croatia - Study Upon a Student Population, Ekonomska istraživanja, Vol. 22, No. 4, str. 100-117

7. Kopecky, P. i Mudde, C. (2002.) The Two Sides of Euroscepticism Party Positions on European Integration in East Central Europe, European Union Politics, Vol. 3, No. 3, str. 297-326

8. Kordić, G. (2011.) Monetarni i fiskalni aspekti euroskepticizma: problemi monetarnih integracija u uvjetima globalne financijske krize, Ekonomija/Economics, Vol. 18, No. 3, str. 609-625

9. Lamza Posavec, V., Ferić, I. i Rihtar, S. (2006.) Nacionalni ponos i otvorenost prema europskim integracijama, Društvena istraživanja, Vol. 15, No. 1-2 (81-82), str. 141-153

10. Milardović, A. (2012.) Tri eseja o euroskepticizmu: o semiotici euroskepticizma, Centar za politološka istraživanja, Zagreb

11. Taggart, P. A., Szczerbiak, A. (2001.) Parties, positions and Europe: Euroscepticism in the EU candidate states of Central and Eastern Europe, SEl working papers, No. 46, Sussex European Institute, str. 1-38 
Summary

\section{EUROSCEPTICISM OF YOUNG PEOPLE IN CROATIA}

The 2009 financial crisis, which resulted in the economic divergence of euro area member states, spurred a rise in Euroscepticism across the European Union. With the expected entry of Croatia into the euro area, the issue of costs and benefits of European integration has become relevant again. The main goal of the paper is to investigate the Euroscepticism of young people in Croatia. The research is conducted on a sample of 405 young people. The analysis is performed using logistic regression. The dependent variable in the model is a binomial variable that describes the respondents' answer to the question of whether or not they support the euro as the official currency in Croatia. The results of the research indicate that significant determinants of youth Euroscepticism are the exclusive national identity and economic expectations. On the one hand, Croatia's accession to the euro area is in a certain collision with a sense of commitment to one's own state in the context of exclusive national identity. In other words, young people who do not see European identity as part of their own identity will be inclined to Euroscepticism. Another important determinant of young people's Euroscepticism is economic expectations, ie their assessment of the advantages and disadvantages of joining the euro area. In other words, young people form an opinion about the euro on the individual and social-economic costs of the euro as the official currency, so those who expect more harm than good will be more prone to Euroscepticism. The results of the research contribute to a better understanding of the determinants of Euroscepticism among young people in Croatia and can be an incentive to further open the media and social space for articulating arguments about the benefits and costs of Croatia's future membership in the Economic and Monetary Union.

Keywords: Economic and Monetary Union, common currency, Euroscepticism, young people, Republic of Croatia. 